\title{
E-governance as a Mechanism for Improving Social Care Services for Homeless O Ider Persons
}

\section{Mervat Gamal El Din Ali Shamroukh (Ph.D)}

Associate Professor Department of Community Organization Faculty of Social Work, Helwan University

\section{Dr. Heba Mohammed Hosny El Eweishy}

Assistant Professor, Department of Community Organization Faculty of Social Work Helwan University 


\section{Abstract:}

This research describes e-governance as a mechanism to improve the services provided to homeless elderly. The dimensions of governance are human resource development, accountability, and transparency. Accordingly, this research aims to determine the level of application of e-governance in institutions for the homeless elderly and the level of services provided to them. One of the study hypotheses is that there is a positive correlation between the application of e-governance and the improvement of social care services provided to the homeless elderly. The study finds this hypothesis true. The results of the study confirm that transparency and accountability are basic indicators for implementing egovernance, and thus they must be applied. The study also provides suggestions for activating e-governance including soliciting the support of information technology experts to develop an effective framework for applying e-governance in the organization and establishing the principle of transparency and in all the work that the organization does to improve the services provided to the homeless elderly.

\section{Keywords:}

E-governance, homeless elderly, Social Care Services

\section{Introduction:}

The technological development that took place in the field of information and communication technology, and the evolution and pervasion of the internet has contributed to the societies' strong entrance into the age of information. Digital methods in this era are a basic communication instrument between individuals and institutions in the public and private sectors, which constitutes a modern lifestyle and work for institutions (Dominguez: 2010, p4).

It is agreed that the success of institutions in achieving their goals requires the presence of systems governing the relationships between the main parties to achieve transparency and accountability and to empower human resources. This is called governance. Many see governance as an active project that forms the basis and the indicator for institutional development in both the public and private sectors (Michael: 200, p.2)

In view of the positive results achieved by governance in all fields, especially societal institutions, and the emergence of new dissemination channels such as the internet and cyberspace, it has become an urgent requirement for institutions to provide their services 
through the virtual world. Management too is required to be in modern technological and electronic form to achieve speed, lower cost, and achieve transparency, fair service delivery, and human resources empowerment. Thus occurred the shift in organizations to apply "e-governance". E-governance is simply the process by which traditional governance is modernized using technology within institutions (Nasereddin: 2018, p.2).

Odawa (2002, p.4) emphasizes that governance is a system of supervision and guidance at the institutional level. In this context, it is clear that the application of e-governance leads to improving the quality of service in organizations, whether governmental or private. Institutions for the homeless elderly should pay attention to the application of e-governance to provide better services especially for this age bracket that has gained a prominent place and an increasing interest in medical, social, and psychological studies. (Fayed,2020, p.6).

The Central Agency for Public Mobilization and Statistics (CAPMAS) in its statement on the International Day of Older Persons states that the number of elderly persons reached 0.6 million (CAPMAS, 2019).

In recent years, the phenomenon of homelessness has become widespread among all groups of society, especially the elderly. In a recent study, Concepcion (2004) indicated that the number of elderly persons is constantly increasing around the world. Weak social and family ties instigate the feelings of isolation, loneliness and depression among the elderly. That's why they are in dire need for specific care.

Amber (2009, p.72) confirms that the elderly face many problems, including deteriorating health, feelings of loneliness and isolation, aggressive behavior, memory loss, psychological depression, and loss of desire for life.

In this context, it is clear that the elderly face many problems that require support to address and to help them cope. Such requirements include the provision of the necessary services and programs, and implementing social protection programs for the elderly. Diversifying social protection mechanisms is necessary when serving the elderly as well as improving their quality of life, and advocating their rights within an effective social policy framework that seeks to achieve equality and social justice (Beales: 2008).

In the context of social work profession, especially the community organization model, NGOs are the most active entities that 
seek to develop communities and empower marginalized groups through the provision of services and programs. There is an agreement that applying e-governance in organizations will increase their efficiency, improve their performance, and make them more transparent Coleman (2006).

Kathryna (2009) emphasizes the necessity of adopting the governance model because of its positive influences on the professional practice of social work within institutions. That is due to the elements of accountability, transparency, and democracy that governance supplies the decision-making process with.

In this context, it is important for institutions to apply egovernance to improve the service tool for homeless older persons. In addition, the application of electronic governance within organizations leads to raising the level of performance, increasing the accuracy of information, keeping pace with technological development, and improving the efficiency and performance of workers in organizations Sharada (2017).

Therefore, this study seeks to define e-governance as a mechanism to improve social care services provided to the homeless elderly.

\section{Importance of the Study:}

1- The effective role that NGOs play in addressing the problems facing the elderly.

2- The importance of electronic governance in enhancing performance, accomplishing tasks, and improving services.

\section{Objectives of the Study:}

1- Determining the level of application of the dimensions of egovernance in institutions providing the homeless elderly with.

2- Determine the level of social care services provided to the homeless elderly.

\section{Study Hypotheses:}

1. First hypothesis: The application of e-governance dimensions as a mechanism for improving social care services provided for the homeless elderly is of medium level. The hypothesis can be tested using three indicators: resources development, accountability, and transparency.

2. Second hypothesis: The level of social care services provided to the homeless elderly is high. The hypothesis can be tested using the three indicators: social services, health services, and economic services. 
3. Third hypothesis: There is a statistically significant positive correlation between the application of e-governance and the improvement of social care services provided to homeless elderly

\section{Study Concepts:}

\section{First: Electronic Governance:}

The procedural definition of e-governance in this study is:

1 - It is a management using information and communication technology in homeless elderly care institutions.

2- These institutions seek, through e-governance, to apply transparency, accountability, and human resource development.

3-Reducing the administrative and organizational burdens of the organization

4- Raising the level of efficiency and effectiveness of performance in providing social care services for the homeless elderly

\section{Second: The concept of social care services}

The procedural definition of social care services in this study:

1 - It is a set of activities and services provided to the homeless elderly

2-It seeks to improve and develop civil societies for the better

3- It includes social care services (economic-social-health services)

\section{The theoretical principles of the study:}

Working with the organization's community Model:

Working with the organization's community means working professionally with organization's components and its own community, to help it serve citizens with increased effectiveness (Ragab 1983, p. 49).

The researchers have benefited from this model in the current study in:

Identifying the difficulties that prevent the practice of egovernance in the homeless elderly care organizations. It has also been useful in identifying the views of beneficiaries on the provided services, improving said services, effectively investing the organizational resources. It has also been beneficial in determining the importance of exchange, coordination, transparency, and accountability within the organization for improving services provided to beneficiaries. 


\section{Methodological Procedures of the Study:}

\section{1- Type of the Study:}

This study is a descriptive study. It aims to assess electronic governance as a mechanism for improving social care services provided to the homeless elderly.

\section{2- Methodology:}

This study is based on the scientific method using census social survey and sample survey:

- Census social survey with the board members, staff, and social workers in Maana Association for Saving Humans number (30).

- purposive sample of 50 individuals based on the following criteria:

- 50 years or older.

- Benefiting from the association's services

- With an available health status to ensure applicability.

- Residents of the association.

\section{3- Study Tools:}

1. A questionnaire used with staff, social workers, and board members of Maana Association for Saving Humans ( $\mathrm{N}=30$ ).

\section{Validity and Reliability:}

The researchers have applied content validity on the tool through review of literature and theoretical frameworks, followed by analyzing the literature, research, and studies to determine the different dimensions related to the problem of the study.

The researchers have also applied face validity on the tool. They have presented the tool to five faculty members at the Faculty of Social Work, Helwan University. Consensus has reached $80 \%$ on the tool validity. The researchers then have produced the tool in its final form.

The researchers have tested the statistical reliability of the tool on a sample 10 individuals of the officials, representing the study population, using Alpha Kronbach coefficient. The reliability coefficient was 0.86 , which is considered a suitable level of statistical reliability.

2. Questionnaire used with a of purposive sample (50) beneficiaries, who have been available for interviewing during implementation. 


\section{Validity and Reliability:}

The researchers have applied content validity on the tool through review of literature and theoretical frameworks, followed by analyzing the literature, research, and studies to determine the different dimensions related to the problem of the study.

The researchers have also applied face validity on the tool. They presented the tool to five faculty members at the Faculty of Social Work, Helwan University. Consensus has reached $80 \%$ on the tool validity. The researchers then have produced the tool in its final form.

The researchers have tested the statistical reliability of the tool on a sample 10 individuals from the homeless elderly category using Alpha Kronbach coefficient. The reliability coefficient was 0.90, which is considered a suitable level of statistical reliability.

\section{4- Study Fields:}

1. Location Field: The framework of the study has targeted non-governmental organizations concerned with providing the homeless elderly with care. The location field for the study has been Maana Association for Saving Humans and its branches in Dokki and Giza. The association has been chosen based on the following criteria:

- The association serves a large number of beneficiaries.

- The association's agreement to apply the research.

- Availability of the sample for implementation of the study.

\section{Human Field:}

1. Census survey with board members, staff, and social workers in Maana Association for Saving Humans in its branches in Sokki and Giza, $(\mathrm{N}=30)$ conducted with all available individuals.

2. A sample of beneficiaries of the association's service is of application range 95. The researchers have applied the study on a purposive sample of 50 individuals based on the following criteria:

- 50 years or older.

- Benefiting from the association's services

- With an available health status to ensure applicability.

- Residents of the association.

\section{Time Field:}

The data collection has been conducted from 10/11/2020 to $16 / 12 / 2020$. 


\section{Results of the Field Study:}

First Axis: Dimensions of E-governance in Care Institutions for the Homeless Elderly:

(1) Huma Resources Development: Table No. (1) Human Resource Development $\mathrm{N}=30$

\begin{tabular}{|c|c|c|c|c|}
\hline Sr. & Statements & Mean & $\begin{array}{l}\text { Standard } \\
\text { Deviation }\end{array}$ & Ranking \\
\hline 1 & $\begin{array}{l}\text { The organization conducts training } \\
\text { courses for workers to increase the } \\
\text { level of e-governance practice }\end{array}$ & 2.47 & $\cdot, 73$ & 2 \\
\hline 2 & $\begin{array}{l}\text { The organization uses experts or } \\
\text { specialists to train workers in using } \\
\text { modern electronic methods }\end{array}$ & 2.23 & $\cdot, 73$ & 6 \\
\hline 3 & $\begin{array}{l}\text { The organization seeks to develop a } \\
\text { strategic plan for training programs to } \\
\text { periodically develop employee } \\
\text { performance on the electronic system }\end{array}$ & 2.37 & $\cdot, 81$ & 4 \\
\hline 4 & $\begin{array}{l}\text { The organization seeks to enhance } \\
\text { employees 'confidence in their ability } \\
\text { to use e-governance applications }\end{array}$ & 2.43 & $\cdot, 68$ & 3 \\
\hline 5 & $\begin{array}{l}\text { The organization implements programs } \\
\text { and projects to increase human } \\
\text { capabilities within the organization to } \\
\text { activate e-governance }\end{array}$ & 2.57 & •,63 & 1 \\
\hline 6 & $\begin{array}{l}\text { The organization seeks to determine } \\
\text { the training needs of officials and } \\
\text { workers in the organization }\end{array}$ & 2.33 & $\cdot, 76$ & 5 \\
\hline \multicolumn{2}{|c|}{ The dimension as a whole } & 2.4 & $\cdot, 58$ & $\begin{array}{l}\text { High } \\
\text { Level }\end{array}$ \\
\hline
\end{tabular}

The table above indicates that:

The level of human resources development as one of the dimensions of e-governance in the care institutions for the homeless elderly care as determined by the organization's officials is high, with an arithmetic mean of 2.4. Based on the ranking of the arithmetic means, the indicators can be listed as follows. The first ranking has involved "The organization implements programs and projects to increase human capabilities within the organization to activate e-governance" with a mean of 2.57. Lastly has come "The organization uses experts or specialists to train workers in using modern electronic methods" with a mean of 2.23. This reflects the organization's desire to implement programs and projects to improve life for the homeless elderly, to improve the capacities of workers, and to develop their 


\begin{tabular}{|lc||}
\hline Egyptian Journal of Social Work (EJSW) & http://ejsw.journals.ekb.eg \\
ISSN: 2356-9204 & Vol 12, Issue 1, June 2021 \\
\hline \hline
\end{tabular}

skills through the training. These results are consistent with the Fahd's study (2018, p. 1), which has found that promoting egovernance and empowerment of human resources through an effective operational strategy has led to the achievement of the organization's goals.

\begin{tabular}{|c|c|c|c|c|}
\hline Sr. & Statements & Mean & $\begin{array}{l}\text { Standard } \\
\text { Deviation }\end{array}$ & Ranking \\
\hline 1 & $\begin{array}{l}\text { The organization has mechanisms } \\
\text { for categorizing programs and } \\
\text { services targeting the homeless } \\
\text { elderly }\end{array}$ & 2.53 & 0.78 & 1 \\
\hline 2 & $\begin{array}{l}\text { There is a mechanism for receiving } \\
\text { complaints from beneficiaries to } \\
\text { organization workers accountable } \\
\text { and assess their performance }\end{array}$ & 2.33 & 0.61 & 3 \\
\hline 3 & $\begin{array}{l}\text { There are clear rules for holding } \\
\text { leaders and relevant cadres } \\
\text { accountable and for making } \\
\text { decisions in case they are proven } \\
\text { negligent in their work. }\end{array}$ & 2.3 & 0.75 & 5 \\
\hline 4 & $\begin{array}{l}\text { The organization is obligated to } \\
\text { submit a statement on its operations }\end{array}$ & 2.33 & 0.66 & 4 \\
\hline 5 & $\begin{array}{l}\text { There is a system in place that } \\
\text { allows for applying accountability } \\
\text { practices towards all workers in the } \\
\text { organization }\end{array}$ & 2.47 & 0.68 & 2 \\
\hline 6 & $\begin{array}{l}\text { The organization conducts an } \\
\text { annual customer satisfaction survey } \\
\text { regarding its services }\end{array}$ & 2.17 & 0.7 & 6 \\
\hline \multicolumn{2}{|c|}{ The dimension as a whole } & 2.36 & 0.51 & $\begin{array}{l}\text { High } \\
\text { Level }\end{array}$ \\
\hline
\end{tabular}

The table above indicates that:

The level of accountability as one of the dimensions of egovernance in the care institutions for the homeless elderly care as determined by the organization's officials is high, with an arithmetic mean of 2.63. Based on the ranking of the arithmetic means, the indicators can be listed as follows. The first ranking has involved "The organization has mechanisms for categorizing programs and services targeting the homeless elderly" with a mean of 2.53. Lastly has come "The organization conducts an annual customer satisfaction survey 


\begin{tabular}{|lc||}
\hline Egyptian Journal of Social Work (EJSW) & http://ejsw.journals.ekb.eg \\
ISSN: 2356-9204 & Vol 12, Issue 1, June 2021 \\
\hline \hline
\end{tabular}

regarding its services" with a mean of 2.17. This reflects the organization's commitment to divide work among employees to improve the services provided to the beneficiaries and to operate with transparency and accountability within the organization. This is confirmed by the theoretical principles of the study, i.e. the organization community working model. It is also in line with Shiva Stava's study (2014, p.57), which emphasizes the importance of the organizational self-evaluation, holding leaders accountable, and the effective application of e-governance in achieving the organization's goals.

Table (3) Transparency N=30

\begin{tabular}{|c|c|c|c|c|}
\hline Sr. & Statements & Mean & $\begin{array}{l}\text { Standard } \\
\text { Deviation }\end{array}$ & Ranking \\
\hline 1 & $\begin{array}{l}\text { The organization has a website } \\
\text { with all data made available }\end{array}$ & 2.6 & 0.72 & 2 \\
\hline 2 & $\begin{array}{l}\text { Electronic communication channels } \\
\text { exist with other organizations to } \\
\text { acquire the needed information for } \\
\text { decision-making }\end{array}$ & 2.43 & 0.82 & 3 \\
\hline 3 & $\begin{array}{l}\text { The organization promotes the } \\
\text { services it provides to the homeless } \\
\text { elderly within the community }\end{array}$ & 2.3 & 0.84 & 6 \\
\hline 4 & $\begin{array}{l}\text { The organization utilizes specific } \\
\text { electronic data flow mechanisms } \\
\text { between organizations specialized } \\
\text { in providing care services for the } \\
\text { homeless elderly }\end{array}$ & 2.4 & 0.77 & 4 \\
\hline 5 & $\begin{array}{l}\text { The organization submits periodic } \\
\text { financial and administrative reports } \\
\text { to relevant government agencies } \\
\text { concerned with care for the } \\
\text { homeless elderly }\end{array}$ & 2.63 & 0.61 & 1 \\
\hline 6 & $\begin{array}{l}\text { The organization employs and } \\
\text { promotes an electronic complaint } \\
\text { and enquiries mechanism on its } \\
\text { services }\end{array}$ & 2.33 & 0.76 & 5 \\
\hline & Dimension as a whole & 2.45 & 0.6 & $\begin{array}{l}\text { High } \\
\text { Level }\end{array}$ \\
\hline
\end{tabular}

The table above indicates that:

The level of transparency as one of the dimensions of egovernance in the care institutions for the homeless elderly care as 
determined by the organization's officials is high, with an arithmetic mean of 2.45. Based on the ranking of the arithmetic means, the indicators can be listed as follows. The first ranking has involved "The organization submits periodic financial and administrative reports to relevant government agencies concerned with care for the homeless elderly" with a mean of 2.63. Lastly, has come "The organization employs and promotes an electronic complaint and enquiries mechanism on its services" with a mean of 2.3. This reflects the organization's high interest in submitting administrative and financial reports to relevant authorities and in pursuing transparency and clarity in all its operations and services. This result is confirmed by Pound's study (1995, p.1), which emphasizes that easy access to information is one of the methods through which organization can reach governance.

Second Axis: Social Care Services Provided for the Homeless Elderly:

Table (4)_Social Services

\begin{tabular}{|c|c|c|c|c|c|c|c|}
\hline \multirow{2}{*}{ Sr. } & \multirow{2}{*}{ Statements } & \multicolumn{3}{|c|}{$\begin{array}{c}\text { Homeless Elderly } \\
(\mathrm{N}=50)\end{array}$} & \multicolumn{3}{|c|}{ Officials ( $\mathbf{N}=\mathbf{3 0}$ ) } \\
\hline & & Mean & $\begin{array}{l}\text { Std. } \\
\text { Dev. }\end{array}$ & $\begin{array}{c}\text { Rank- } \\
\text { ing }\end{array}$ & Mean & $\begin{array}{l}\text { Std. } \\
\text { Dev. }\end{array}$ & $\begin{array}{c}\text { Rank- } \\
\text { ing }\end{array}$ \\
\hline 1 & $\begin{array}{l}\text { The organization } \\
\text { supports the elderly } \\
\text { to adapt to the new } \\
\text { life in the } \\
\text { organization }\end{array}$ & 2.94 & 0.24 & 1 & 2.77 & 0.5 & 1 \\
\hline 2 & $\begin{array}{l}\text { The organization } \\
\text { helps the homeless } \\
\text { elderly take part in in } \\
\text { public life }\end{array}$ & 2.82 & 0.39 & 3 & 2.63 & 0.49 & 3 \\
\hline 3 & $\begin{array}{l}\text { Reducing the } \\
\text { elderly's sense of } \\
\text { aging through their } \\
\text { presence with others } \\
\text { in the organization }\end{array}$ & 2.76 & 0.52 & 5 & 2.33 & 0.61 & 5 \\
\hline 4 & $\begin{array}{l}\text { The organization } \\
\text { solves conflicts that } \\
\text { occur between the } \\
\text { elderly in the } \\
\text { organization }\end{array}$ & 2.8 & 0.4 & 4 & 2.57 & 0.5 & 4 \\
\hline 5 & $\begin{array}{l}\text { The organization } \\
\text { provides suitable }\end{array}$ & 2.9 & 0.3 & 2 & 2.67 & 0.55 & 2 \\
\hline
\end{tabular}




\begin{tabular}{|lr||}
\hline Egyptian Journal of Social Work (EJSW) & http://ejsw.journals.ekb.eg \\
ISSN: 2356-9204 & Vol 12, Issue 1, June 2021 \\
\hline \hline
\end{tabular}

\begin{tabular}{|c|c|c|c|c|c|c|c|}
\hline \multirow{2}{*}{ Sr. } & \multirow{2}{*}{ Statements } & \multicolumn{3}{|c|}{$\begin{array}{c}\begin{array}{c}\text { Homeless Elderly } \\
(\mathrm{N}=50)\end{array} \\
\end{array}$} & \multicolumn{3}{|c|}{ Officials $(\mathbf{N}=\mathbf{3 0})$} \\
\hline & & Mean & $\begin{array}{l}\text { Std. } \\
\text { Dev. }\end{array}$ & $\begin{array}{c}\text { Rank- } \\
\text { ing }\end{array}$ & Mean & $\begin{array}{l}\text { Std. } \\
\text { Dev. }\end{array}$ & $\begin{array}{c}\text { Rank- } \\
\text { ing }\end{array}$ \\
\hline & $\begin{array}{l}\text { accommodation for } \\
\text { the homeless elderly }\end{array}$ & & & & & & \\
\hline 6 & $\begin{array}{l}\text { The organization } \\
\text { employs social } \\
\text { workers to help the } \\
\text { elderly cope with } \\
\text { their social problems }\end{array}$ & 2.72 & 0.54 & 6 & 2.3 & 0.84 & 6 \\
\hline \multicolumn{2}{|c|}{ Dimension as a whole } & 2.82 & 0.34 & $\begin{array}{l}\text { High } \\
\text { Level } \\
\end{array}$ & 2.54 & 0.45 & $\begin{array}{l}\text { High } \\
\text { Level }\end{array}$ \\
\hline
\end{tabular}

The table above indicates that:

The level of social services provided for homeless elderly care as determined by the elderly is high, with an arithmetic mean of 2.82 . Based on the ranking of the arithmetic means, the indicators can be listed as follows. The first ranking has involved "The organization supports the elderly to adapt to the new life in the organization" with a mean of 2.94. Lastly in the 6th ranking has come "The organization employs social workers to help the elderly cope with their social problems" with a mean of 2.72 .

The level of social services provided for homeless elderly care as determined by the officials is high, with an arithmetic mean of 2.54. Based on the ranking of the arithmetic means, the indicators can be listed as follows. The first ranking has involved "The organization supports the elderly to adapt to the new life in the organization" with a mean of 2.77. Lastly, in the $6^{\text {th }}$ rank has come "The organization employs social workers to help the elderly cope with their social problems" with a mean of 2.3 .

These results indicate that both beneficiaries and officials have close views regarding the organization's provision of social services. Such results reflect the organization's commitment to provide all types of social services for beneficiaries and to rehabilitate the homeless elderly to help them adapt to their new life at the organization. 


\begin{tabular}{|lr||}
\hline Egyptian Journal of Social Work (EJSW) & http://ejsw.journals.ekb.eg \\
ISSN: 2356-9204 & Vol 12, Issue 1, June 2021 \\
\hline \hline
\end{tabular}

Table (5) Health Services

\begin{tabular}{|c|c|c|c|c|c|c|c|}
\hline \multirow{2}{*}{$\begin{array}{c}\mathrm{Sr} \\
.\end{array}$} & \multirow{2}{*}{ Statements } & \multicolumn{3}{|c|}{$\begin{array}{c}\text { Homeless Elderly } \\
(\mathrm{N}=\mathbf{5 0})\end{array}$} & \multicolumn{3}{|c|}{ Officials $(\mathrm{N}=\mathbf{3 0})$} \\
\hline & & Mean & $\begin{array}{l}\text { Std. } \\
\text { Dev. }\end{array}$ & $\begin{array}{c}\text { Rank } \\
\text {-ing }\end{array}$ & Mean & $\begin{array}{l}\text { Std. } \\
\text { Dev. }\end{array}$ & $\begin{array}{c}\text { Rank } \\
\text {-ing }\end{array}$ \\
\hline 1 & $\begin{array}{l}\text { The organization is } \\
\text { conducts periodic } \\
\text { medical examinations of } \\
\text { elderly residents }\end{array}$ & 2.88 & 0.33 & 1 & 2.33 & 0.8 & 3 \\
\hline 2 & $\begin{array}{l}\text { The organization } \\
\text { provides first aid } \\
\text { services in case of } \\
\text { emergency }\end{array}$ & 2.86 & 0.35 & 2 & 2.2 & 0.71 & 4 \\
\hline 3 & $\begin{array}{l}\text { The organization } \\
\text { provides the necessary } \\
\text { nutrition and hygiene } \\
\text { services for the elderly }\end{array}$ & 2.88 & 0.33 & 1 & 2.37 & 0.76 & 2 \\
\hline 4 & $\begin{array}{l}\text { Providing prosthetic } \\
\text { devices for elderly } \\
\text { people as needed } \\
\end{array}$ & 2.78 & 0.42 & 3 & 2.13 & 0.73 & 5 \\
\hline 5 & $\begin{array}{l}\text { The organization holds } \\
\text { health awareness } \\
\text { seminars for the } \\
\text { homeless elderly }\end{array}$ & 1.92 & 0.88 & 4 & 2.43 & 0.63 & 1 \\
\hline 6 & $\begin{array}{l}\text { The organization } \\
\text { provides a health card } \\
\text { for each elderly } \\
\text { residents }\end{array}$ & 1.92 & 0.88 & 4 & 2.13 & 0.73 & 5 \\
\hline & ension as a whole & 2.54 & 0.36 & $\begin{array}{l}\text { High } \\
\text { Level }\end{array}$ & 2.27 & 0.55 & $\begin{array}{c}\text { Medi } \\
\text { um } \\
\text { Level }\end{array}$ \\
\hline
\end{tabular}

The table above indicates that:

The level of health services provided for homeless elderly care as determined by the elderly is high, with an arithmetic mean of 2.54. Based on the ranking of the arithmetic means, the indicators can be listed as follows. The first ranking has involved "The organization is conducts periodic medical examinations of elderly residents" and "The organization provides the necessary nutrition and hygiene services for the elderly" both with a mean of 2.88. Lastly in the 4th ranking has come "The organization holds health awareness seminars for the homeless elderly" and "The organization provides a health card for each elderly resident" both a mean of 1.92 . 


\begin{tabular}{|lc||}
\hline Egyptian Journal of Social Work (EJSW) & http://ejsw.journals.ekb.eg \\
ISSN: 2356-9204 & Vol 12, Issue 1, June 2021 \\
\hline \hline
\end{tabular}

The level of health services provided for homeless elderly care as determined by the officials is medium, with an arithmetic mean of 2.27. Based on the ranking of the arithmetic means, the indicators can be listed as follows. In the first ranking was "The organization holds health awareness seminars for the homeless elderly" with a mean of 2.43. Lastly, in the 5th rank has come "Providing prosthetic devices for elderly people as needed" and "The organization provides a health card for each elderly resident" both with a mean of 2.13.

The table shows that:

These results indicate that both beneficiaries and officials have close views regarding the organization's provision of health services. Such results reflect the organization's commitment to conduct periodic health examinations for elderly residents, provide nutrition and hygiene services, and provide those in need with prosthetic devices. The researchers attribute the organization's commitment to its possession of the needed capacities for providing health services to the beneficiaries.

\section{Table (6) Economic Services}

\begin{tabular}{|c|c|c|c|c|c|c|c|}
\hline \multirow{2}{*}{$\begin{array}{c}\mathrm{Sr} \\
\text { • }\end{array}$} & \multirow{2}{*}{ Statements } & \multicolumn{3}{|c|}{$\begin{array}{c}\text { Homeless Elderly } \\
(\mathrm{N}=\mathbf{5 0})\end{array}$} & \multicolumn{3}{|c|}{ Officials $(\mathbf{N}=30)$} \\
\hline & & Mean & $\begin{array}{l}\text { Std. } \\
\text { Dev. }\end{array}$ & $\begin{array}{c}\text { Rank } \\
\text {-ing }\end{array}$ & Mean & $\begin{array}{l}\text { Std. } \\
\text { Dev. }\end{array}$ & $\begin{array}{c}\text { Rank } \\
\text {-ing }\end{array}$ \\
\hline 1 & $\begin{array}{l}\text { The organization trains } \\
\text { the elderly on light } \\
\text { vocations that suit their } \\
\text { capabilities to provide } \\
\text { them with an income }\end{array}$ & 2.7 & 0.54 & 1 & 2.53 & 0.68 & 1 \\
\hline 2 & $\begin{array}{l}\text { The organization } \\
\text { facilitates the elderly's } \\
\text { access to social security } \\
\text { services to improve their } \\
\text { conditions }\end{array}$ & 2.02 & 0.89 & 3 & 2.4 & 0.62 & 2 \\
\hline 3 & $\begin{array}{l}\text { The organization } \\
\text { provides the elderly } \\
\text { with the necessary } \\
\text { funding for small } \\
\text { projects that suit them }\end{array}$ & 2.68 & 0.59 & 2 & 2.03 & 0.76 & 5 \\
\hline 4 & $\begin{array}{l}\text { The organization } \\
\text { provided the elderly } \\
\text { with soft loans to } \\
\text { improve their conditions }\end{array}$ & 1.8 & 0.78 & 5 & 2.4 & 0.67 & 3 \\
\hline 5 & $\begin{array}{l}\text { The organization helps } \\
\text { the elderly obtain }\end{array}$ & 1.94 & 0.91 & 4 & 2.17 & 0.79 & 4 \\
\hline
\end{tabular}




\begin{tabular}{|lc||}
\hline Egyptian Journal of Social Work (EJSW) & http://ejsw.journals.ekb.eg \\
ISSN: 2356-9204 & Vol 12, Issue 1, June 2021 \\
\hline \hline
\end{tabular}

\begin{tabular}{|c|c|c|c|c|c|c|c|}
\hline \multirow[t]{2}{*}{$\mathrm{Sr}$} & \multirow{2}{*}{ Statements } & \multicolumn{3}{|c|}{$\begin{array}{c}\text { Homeless Elderly } \\
(\mathrm{N}=50)\end{array}$} & \multicolumn{3}{|c|}{ Officials $(\mathbf{N}=\mathbf{3 0})$} \\
\hline & & Mean & $\begin{array}{l}\text { Std. } \\
\text { Dev. }\end{array}$ & $\begin{array}{c}\text { Rank } \\
\text {-ing }\end{array}$ & Mean & $\begin{array}{l}\text { Std. } \\
\text { Dev. }\end{array}$ & $\begin{array}{c}\text { Rank } \\
\text {-ing }\end{array}$ \\
\hline & $\begin{array}{l}\text { financial aid from other } \\
\text { institutions }\end{array}$ & & & & & & \\
\hline Dir & ension as a whole & 2.23 & 0.52 & $\begin{array}{c}\text { Med- } \\
\text { ium } \\
\text { Level }\end{array}$ & 2.31 & 0.53 & $\begin{array}{c}\text { Med- } \\
\text { ium } \\
\text { Level }\end{array}$ \\
\hline
\end{tabular}

The table above indicates that:

The level of economic services provided for homeless elderly care as determined by the elderly is medium, with an arithmetic mean of 2.23. Based on the ranking of the arithmetic means, the indicators can be listed as follows. The first ranking has involved "The organization trains the elderly on light vocations that suit their capabilities to provide them with an income" with a mean of 2.7. Lastly, in the 5th ranking has come "The organization provided the elderly with soft loans to improve their conditions" with a mean of 1.8 .

The level of economic services provided for homeless elderly care as determined by the officials is medium, with an arithmetic mean of 2.31. Based on the ranking of the arithmetic means, the indicators can be listed as follows. The first ranking has been "The organization trains the elderly on light vocations that suit their capabilities to provide them with an income" with a mean of 2.53. Lastly in the 5th rank has come "Providing prosthetic devices for elderly people as needed" and "The organization provides the elderly with the necessary funding for small projects that suit them" both with a mean of 2.03.

These results indicate that both beneficiaries and officials have close views regarding the organization's provision of economic services. Such results reflect the organization's commitment to provide the elderly with opportunities for practicing light vocations that suits them, to facilitate their acquiring of income, and to help reduce their feeling of need and dependence. This result is in line with Griffith's study (2002) that emphasizes the necessity of satisfying the economic needs of the elderly and reducing their feeling of need through strengthening their economic security and providing them with suitable solutions. 


\section{Third Axis: Testing the Study Hypotheses:}

(1) Testing the First Hypothesis of the Study: The application of egovernance dimensions as a mechanism for improving social care services provided for the homeless elderly is of medium level.

Table (7): The Level of Application for E-governance As a Whole in Homeless Elderly Care Organization as Determined by Officials $\mathrm{N}=30$

\begin{tabular}{||l||l||r||r||c||}
\hline \hline Sr. & \multicolumn{1}{|c|}{ Dimensions } & Mean & Std. Dev. & Ranking \\
\hline \hline 1 & Human Resources Development & $\mathbf{2 . 4}$ & $\mathbf{0 . 5 8}$ & $\mathbf{2}$ \\
\hline \hline 2 & Accountability & $\mathbf{2 . 3 6}$ & $\mathbf{0 . 5 1}$ & $\mathbf{3}$ \\
\hline \hline 3 & Transparency & $\mathbf{2 . 4 5}$ & $\mathbf{0 . 6}$ & $\mathbf{1}$ \\
\hline \hline E-governance Dimensions as a Whole & $\mathbf{2 . 4}$ & $\mathbf{0 . 5 4}$ & High Level \\
\hline
\end{tabular}

The table above indicates that:

The level of e-governance application in homeless elderly care institutions as a whole, as determined by officials is high, with an arithmetic mean of 2.4. Based on the ranking of the arithmetic means, the indicators can be listed as follows. In the first ranking has been transparency with a mean of 2.45 , followed by human resources development, with a mean of 2.4. Finally, in the third rank has been accountability, with a mean of 2.36 .

This proves the validity of the first hypothesis of the study "The application of e-governance dimensions as a mechanism for improving social care services provided for the homeless elderly is of medium level".

(2) Testing the second hypothesis test of the study: The level of social care services provided to the homeless elderly is high.

Table (8)The Level of Social Care Services Provided to the Homeless Elderly as a Whole, as Determined by Officials

\begin{tabular}{|c|c|c|c|c|c|c|c|}
\hline \multirow{2}{*}{$\mathrm{Sr}$} & \multirow{2}{*}{ Dimensions } & \multicolumn{3}{|c|}{$\begin{array}{c}\text { Homeless Elderly } \\
(\mathrm{N}=\mathbf{5 0})\end{array}$} & \multicolumn{3}{|c|}{ Officials $(\mathrm{N}=\mathbf{3 0})$} \\
\hline & & Mean & $\begin{array}{l}\text { Std. } \\
\text { Dev. }\end{array}$ & $\begin{array}{c}\text { Rank } \\
\text {-ing }\end{array}$ & Mean & $\begin{array}{l}\text { Std. } \\
\text { Dev. }\end{array}$ & $\begin{array}{c}\text { Rank } \\
\text {-ing }\end{array}$ \\
\hline 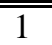 & Social Services & 2.82 & $\overline{0.34}$ & 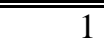 & $\overline{2.54}$ & $\overline{0.45}$ & 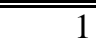 \\
\hline 2 & Health Services & 2.54 & 0.36 & 2 & 2.27 & 0.55 & 3 \\
\hline 3 & Economic Services & 2.23 & 0.52 & 3 & 2.31 & 0.53 & 2 \\
\hline \multicolumn{2}{|c|}{$\begin{array}{l}\text { Social Care Services as a } \\
\text { Whole }\end{array}$} & 2.53 & 0.34 & $\begin{array}{l}\text { High } \\
\text { Level }\end{array}$ & 2.37 & 0.48 & $\begin{array}{l}\text { High } \\
\text { Level }\end{array}$ \\
\hline
\end{tabular}

The table above indicates that:

The level of social care services provided to the homeless elderly, as determined by the elderly is high, with an arithmetic mean 
of 2.53. Based on the ranking of the arithmetic means, the indicators can be listed as follows. The first ranking has involved social services with a mean of 2.82 , followed by health services, with a mean of 2.54 . Finally, in the third rank has come economic services, with a mean of 2.23 .

The level of social care services provided to the homeless elderly, as determined by officials, is high, with an arithmetic mean of 2.37. Based on the ranking of the arithmetic means, the indicators can be listed as follows. The first ranking has involved social services with a mean of 2.54, followed by economic services, with a mean of 2.31 . Finally, in the third rank has come health services, with a mean of 2.27 .

This proves the validity of the second hypothesis of the study "The level of social care services provided to the homeless elderly is high".

(3) Testing the third hypothesis of the study: There is a statistically significant positive correlation between the application of egovernance and the improvement of social care services provided to homeless elderly

Table (9) Correlation between the Application of E-governance and the Improvement of Social Services Provided for the Homeless Elderly as Determined by Officials $\mathrm{N}=30$

\begin{tabular}{||c||c||c||c||c||c||}
\hline \hline Sr. & Dimensions & $\begin{array}{c}\text { Social } \\
\text { Services }\end{array}$ & $\begin{array}{c}\text { Health } \\
\text { Services }\end{array}$ & $\begin{array}{c}\text { Economic } \\
\text { Services }\end{array}$ & $\begin{array}{c}\text { All } \\
\text { Services }\end{array}$ \\
\hline \hline 1 & $\begin{array}{l}\text { Human Resource } \\
\text { Development }\end{array}$ & $0.893^{* *}$ & $0.829^{* *}$ & $0.833^{* *}$ & $0.911^{* *}$ \\
\hline \hline 2 & Accountability & $0.841^{* *}$ & $0.908^{* *}$ & $0.926^{* *}$ & $0.959^{* *}$ \\
\hline \hline 3 & Transparency & $0.947^{* *}$ & $0.684^{* *}$ & $0.707^{* *}$ & $0.825^{* *}$ \\
\hline \hline $\begin{array}{c}\text { E-governance Dimensions as } \\
\text { a Whole }\end{array}$ & $\mathbf{0 . 9 4 1 * *}$ & $\mathbf{0 . 8 4 1 * *}$ & $\mathbf{0 . 8 5 7 * *}$ & $\mathbf{0 . 9 3 9 * *}$ \\
\hline
\end{tabular}

* Significant at (0.05)

The table indicates that:

There is a statistically significant positive correlation at a significance level 0.01 between the application of e-governance and the improvement of social care services provided to the homeless elderly, as determined by the officials. The e-governance dimensions most linked to the improvement of social care services provided for the homeless elderly are in order: accountability, followed by human resource development, and finally, transparency.

This proves the validity of the third hypothesis of the study "There is a statistically significant positive correlation between the 
application of e-governance and the improvement of social care services provided to homeless elderly".

Table (10) Simple Regression Analysis of the Correlation between the Application of E-governance and the Improvement of Social Services Provided for the Homeless Elderly as Determined by Officials $\mathrm{N}=30$

\begin{tabular}{|c|c|c|c|c|c|}
\hline $\begin{array}{c}\text { Independent } \\
\text { Variable }\end{array}$ & $\begin{array}{c}\text { Beta } \\
\text { Regression } \\
\text { Coefficient } \\
\text { (B) }\end{array}$ & T-Test & F-Test & $\begin{array}{l}\text { Correlation } \\
\text { Coefficient } \\
\text { (R) }\end{array}$ & $\begin{array}{l}\text { Coefficient of } \\
\text { Determination } \\
\qquad\left(\mathbf{R}^{2}\right)\end{array}$ \\
\hline $\begin{array}{c}\begin{array}{c}\text { All dimensions } \\
\text { of e- } \\
\text { governance }\end{array} \\
\end{array}$ & $\cdot, 833$ & $14.490 * *$ & $209.973 * *$ & $\cdot, 939 * *$ & $\cdot, 882$ \\
\hline
\end{tabular}

* Significant at (0.05)

The table above indicates that:

The value of the correlation coefficient between the independent variable "Dimensions of implementing e-governance as a whole" and the dependent variable "Dimensions of improving social care services provided to the homeless elderly as a whole" as determined by officials is 0.939), which is statistically significant at a significance level of 0.01. It indicates the existence of a positive correlation between variables.

This proves the validity of the third hypothesis of the study "There is a statistically significant positive correlation between the application of e-governance and the improvement of social care services provided to homeless elderly".

\section{Discussion:}

The results of the study have responded to the set hypotheses. The first hypothesis has been "the application for e-governance dimensions as a mechanism for improving social care services provided for the homeless elderly is of medium level (dimensions of human resource development, accountability, and transparency)". Results have confirmed that the level of application of electronic governance dimensions in homeless elderly care institutions is high. The results of the study have also confirmed that transparency is one of the most important mechanisms used by organizations providing care for the homeless elderly in applying e-governance. The organization submits financial and administrative reports to relevant government agencies concerned with homeless elderly care. This finding is consistent with Pound's study (1999), which has emphasized that easy access to necessary information is one of the most important practices that leads organizations to the application of governance and to reaching its goals. 
This is in line with the theoretical principle of the study, i.e. working with the organization's community model. The model emphasizes the importance of sharing data and information on the organization among all employees to ensure transparency and clarity on made decisions. This is considered one of the most important factors of success for achieving the goals of the organization.

The study results have confirmed the truth of the second hypothesis, which has been "the level of social care services provided to the homeless elderly is high." Thus, the second hypothesis is accepted to be true. These services include health services, social services, and economic services. The study has indicated that the organization provides the homeless elderly with social services, where it supports their rehabilitation and ensures their ability to cope with their new life in the organization. The organization also seeks to provide them with suitable accommodation, as asserted by Abdel Latif (2019) in his study, which emphasizes the effective role of NGOs in empowering marginalized groups socially, economically, and healthily. Moreover, Beals (2008) has highlighted in his study the importance of improving the quality of life for the elderly, advocating for their rights, and providing them with social protection programs.

It is thus clear that NGOs have an important and effective role in addressing the problems facing the homeless elderly and in providing them with services for improving their quality of life.

Results related to the third hypothesis confirm that a positive correlation between the application of e-governance and the improvement of social care services provided to the homeless elderly exists. Results of the study have also indicated that the most applied elements of e-governance are accountability, human resources, and transparency. However, despite the efforts exerted by NGOs in applying electronic governance in improving service provision for the homeless elderly, many difficulties still face organizations in this regard. Such difficulties include lack of a database on the organization's operations and lack of funding sources. This is confirmed by Sahel (2006), which indicates that there are many difficulties facing NGOs including the absence of a database, information, and planning.

The researchers have found that there is a set of suggestions for applying e-governance as an instrument for improving social care services provided to the homeless elderly. These mechanism are: 
1- Engaging information technology experts in developing an effective framework for implementing e-governance in the organization.

2- Establishing the principle of transparency in light of the services provided by the organization.

3- The organization utilizing electronic monitoring mechanisms for assessing performance in accordance with recognized standards to improve services for the homeless elderly.

\section{References:}

Abdel Latif, B. (2016): Identifying the Needs of Marginalized Groups to Achieve Social Security, the 25th Scientific Conference, Faculty of Social Work, Fayoum University.

Abul-Naga Al-Emari (2009): Accountability and Achieving Good Balanced Performance in Social Organizations, a research published in the Journal of the Faculty of Social Work, Helwan University, Issue Twenty-seventh, Part one.

Amber ,Cloder bank (2009) : Social support and Behavioral out comes psychology Adler school of professional .

Backus, Michael(2001) : E- governance and developing countries, international institute for communication and development, Research report - no.3,April,2.

Bales(2008) : Implications of Ageing for social protections and Womens prestentation to it erparlianmentory Vuion,puliloseminar on woman .

Central Agency for Public Mobilization and Statistics (CAPMAS) (2019).

Coeman.S(2006) : African E- governance opportunities and Challenges, University of Oxford Univercity press .

Concepicion , Maria ,Abusesheg (2004) : Valution media legally entice Delos Ligencess Mattreatren lasper Somasen eastrllany loony catbrierd ervalla spoun.

Fahd, N. (2018): The Impact of E-Governance in Enhancing Transparency and Disclosure in Kuwaiti Islamic Banks, School of Economics and Administrative Sciences, Kuwait, p.1.

Fayed, A. Muhammad (2020): The Contributions of NGOs in Achieving Social Protection for the Homeless Elderly, Journal of Studies in Social Work and Human Sciences, Issue 50, Volume 2, April 2020.

Gamil, S. El-Sha'er (2017): Societal Factors Associated with Violence against the Elderly and the Role of Social Work in Dealing with It, PhD Thesis, Faculty of Arts, Alexandria University.

Griffith - Terenca - deans(2002) : The relationship between death Awareness and Successful aging among older adults ,the foridlaa - state university .

Katheryn,Frahm and Martin ,Lawrencel , (2009) : from Governments to governance Implication for social work Administration in social work journal , Taylor, Francis Group, London, vol33.

Nasser Al-Din, H. Hassan (2018): Trends of E-governance Application in Jordanian Private Universities and Its Impact on University Performance Distinction, A Field Study, Middle East University.

Nuria Rodriguez Dominguez, Chrles Bastos Rodriguez(2010) :Introduction to Egovernment, Atos origin,Sara Jevo,April,4.

Odawa Dele (2002) : Introduction and public administration th 21 century research and training prospect us (international, review of administrative science, vo3,p346. 


\begin{tabular}{|lc||}
\hline Egyptian Journal of Social Work (EJSW) & http://ejsw.journals.ekb.eg \\
ISSN: 2356-9204 & Vol 12, Issue 1, June 2021 \\
\hline
\end{tabular}

Pound ,John(1999) : The promise of the governance corporate (Harved business review vol April.

Sharada ,Ravob.S(2017): Information technology governance in public organization volume (38), Springer international publishing AG.

Shrivastava ,R.K.Raizada,A.K\& Saxena .N(2014): Role of governance to strengthen higer education system in India Io SR.8 journal of research \&method in Education (Iosr-jRme)4,p47-62 .

W .Sahel (2006) : Capacity building mary community organization net working strategies for in fluencing public policy (us AToronto urban Education ,V.19m,3m,17oct. 